\title{
Allogeneic Mesenchymal Stem Cells Injections for the Treatment of Bronchiolitis Obliterans Syndrome Following Allogeneic Hematopoietic Stem Cells Transplant
}

\author{
Wei Liang ${ }^{1,2 *}$, Hailong Xia ${ }^{2}$, Yongqing Wang ${ }^{2}$ and Robert Chunhua Zhao ${ }^{2}$ \\ ${ }^{1}$ The First Affiliated Hospital of Anhui Medical University, Hefei, Anhui Province, China \\ ${ }^{2}$ Institute of Basic Medical Science and School of Basic Medicine, Center of Excellence in Tissue Engineering, Chinese Academy of Medical Science and Peking Union \\ Medical College and Tsinghua University, Beijing, China
}

\begin{abstract}
Bronchiolitis Obliterans Syndrome (BOS) is a well-recognized complication of allogeneic Hematopoietic Stem Cell Transplantation (HSCT). The management of bronchiolitis obliterans has been frustrating, with patients developing progressive Air Flow Obstruction (AFO). The purpose of this study was to evaluate the efficacy of human Bone Marrow Derived Mesenchymal Stem Cells (BMMSC) as the salvage therapy for BOS after HSCT. One patient with BOS received intravenous infusions of BMMSC at a dose of $1.5 \times 10^{6} / \mathrm{kg}$ per patients' weight, and rapid recovery from BOS without any side effects was observed. We concluded that BMMSC seems to be a promising therapeutic method in patients with BOS after HSCT.
\end{abstract}

Keywords: Bronchiolitis obliterans syndrome; Mesenchymal stem cells; Hematopoietic stem cells transplantation; Graft-versus-hostdisease

Abbreviations: BOS: Bronchiolitis Obliterans Syndrome; GVHD: Graft Versus Host Disease; AFO: Air Flow Obstruction; CMV: Cytomegalovirus; HSCT: Hematopoietic Stem Cell Transplantation; hVOD: Hepatic Veno-Occlusive Disease

\section{Introduction}

Bronchiolitis Obliterans Syndrome (BOS) is the most common lateonset noninfectious pulmonary complication following HSCT which is associated with substantial morbidity and mortality in adult patients $[1,2]$. Current estimates in the literature suggest that approximately $2 \%$ to $3 \%$ of all allogeneic HSCT recipients and $6 \%$ of patients who develop Chronic Graft-Versus-Host Disease (cGVHD) will develop this syndrome [3-5]. However, based on recent studies it is likely that the true incidence of BOS is probably much higher [6].

The mechanism under BOS is still unclear. Allorecognition of lung antigens mediated immune process may play crucial roles in this complication, because BOS is most commonly seen following lung transplantation and HSCT in association with chronic GVHD [7].

The treatment of BOS is similar to that of chronic GVHD and consists of high dose systemic corticosteroids and immunosuppressive therapy [8]. Despite aggressive immunosuppressive therapy the eventual outcome for these patients is unsatisfactory. Consistent with previous reports, patients with BOS experienced a $40 \%$ non-relapse mortality, significantly greater than those without BOS $[9,10]$. Thus clinical trials of new or novel therapies are needed.

Recently, human MSC attracted more and more attention in treatment of varieties of human diseases such as osteogenisis imperfecta, diabetes and myocardial infarction and so on $[11,12]$. The low immunogenicity makes them the ideal seed cells in cell therapy. Furthermore, the immune regulatory potential of MSCs has been highlighted because they could suppress immune responses in vivo and in vitro by inhibiting $\mathrm{T}$ lymphocyte cells proliferation, thus representing a novel treatment method for Graft-Versus-Host Disease (GVHD) [13]. This also suggests that administration of MSC may represent a novel therapeutic strategy for immune-mediated BOS. Here, we describe first report of our successful experience of using Human Bone Marrow Derived MSC (BMMSC) to treat BOS after failing conventional treatment options.

\section{Materials and Methods \\ BMMSC preparation and injection}

Human BMs were collected after obtaining informed necessary consent from donor. All the procedures were approved by the Ethics Committee at Anhui Medical University and have therefore been performed in accordance with the ethical standards laid down in the 1964 Declaration of Helsinki. Briefly [14], BM aspirates were collected from the posterior iliac crest under local anesthesia and mononuclear cells were obtained by Ficoll-Paque density gradient centrifugation, the interface was collected, and resuspended in Dulbecco's modified Eagle medium (low glucose DMEM/F12), supplemented with 40\% MCDB201 (Sigma), 2\% fetal bovine serum (Gibco Life Technologies, Paisley, UK), 1-insulin transferring selenium (Gibco Life Technologies), $10^{9}$ $\mathrm{M}$ dexamethasone (Sigma), $10^{4} \mathrm{M}$ ascorbic acid 2-phosphate (Sigma), $10 \mathrm{ng} / \mathrm{mL}$ epidermal growth factor (Sigma), and $10 \mathrm{ng} / \mathrm{mL}$ plateletderived growth factor $\mathrm{BB}$ (Sigma), $100 \mathrm{U} / \mathrm{ml}$ penicillin, and 1,000 U/ml streptomycin (Gibco) and then plated in a culture flask $\left(1 \times 10^{6} \mathrm{cells} / \mathrm{mL}\right)$ in a humidified environment of $5 \% \mathrm{CO}_{2}$ at $37^{\circ} \mathrm{C}$. After 24 to 48 hours, nonadherent cells were removed and the adherent layer was cultured until it reached $70 \%$ to $80 \%$ confluence. Cells were then detached with $0.05 \%$ trypsin and $0.01 \%$ ethylenediamine tetraacetic acid and replaced

*Corresponding author: Wei Liang M.D, The Department of Oncology, The Firs Affiliated Hospital of Anhui Medical University, China, Tel/Fax: 86-0551-2922844 E-mail: williamleung@163.com

Received June 13, 2012; Accepted July 06, 2012; Published July 09, 2012

Citation: Liang W, Xia H, Wang Y, Zhao RC (2012) Allogeneic Mesenchymal Stem Cells Injections for the Treatment of Bronchiolitis Obliterans Syndrome Following Allogeneic Hematopoietic Stem Cells Transplant. J Cancer Sci Ther 4: 185-187. doi:10.4172/1948-5956.1000138

Copyright: ( 2012 Liang W, et al. This is an open-access article distributed under the terms of the Creative Commons Attribution License, which permits unrestricted use, distribution, and reproduction in any medium, provided the original author and source are credited. 
Citation: Liang W, Xia H, Wang Y, Zhao RC (2012) Allogeneic Mesenchymal Stem Cells Injections for the Treatment of Bronchiolitis Obliterans Syndrome Following Allogeneic Hematopoietic Stem Cells Transplant. J Cancer Sci Ther 4: 185-187. doi:10.4172/1948-5956.1000138

[15]. The culture expanded cells were assayed in a flow cytometer (FAC Sort, Becton Dickson, and San Jose. CA, USA) and the data analyzed with Cell quest software (Becton Dickinson). BMMSCs were positive for CD29, CD44, CD105, and CD106, but failed to express CD31, CD34, CD45, and HLA-DR (Data not shown). The cells were cultured negative for bacteria, mycoplasma, and fungi before infusion.

\section{Results}

A 38 year old female patient was referred to our clinic in December 2009 with dizziness and asthenia, She was then diagnosed as acute myeloid leukemia type M5 and after 4 consecutive standard chemotherapies, she achieved a complete remission. In October 2010, She received allo-peripheral blood haematopoietic stem cells (containing $3.61 \times 10^{6} / \mathrm{kg} \mathrm{CD} 34^{+}$cells and $3.04 \times 10^{8} / \mathrm{kg}$ mononuclear cells) combined with bone marrow transplantation (containing $1.13 \times 10^{6} / \mathrm{kg} \mathrm{CD} 34^{+}$cells and $1.55 \times 10^{8} / \mathrm{kg}$ mononuclear cells) from a leukocyte antigen (HLA) matched sibling. The conditioning regimen was classical Busulfan and cyclophosphamide (BuCy) method consisting of busulfan $\left(3.2 \mathrm{mg} \mathrm{kg}^{-1}\right.$. day $\left.{ }^{-1}\right)$ intravenously from days -7 to -3 ; cyclophosphamide $\left(1.8 \mathrm{~g} \mathrm{~m}^{-2}\right.$ day $\left.^{-1}\right)$ intravenously from day -3 to -2 .

The patient also received CsA and methotrexate (MTX) to prevent GVHD. The dosage of MTX was $15 \mathrm{mg} / \mathrm{m}^{2}$ intravenously on day +1 , followed by $10 \mathrm{mg} / \mathrm{m}^{2}$ intravenously on day $+3,+6$ and +11 after transplantation. The dosage of CsA was $2.5 \mathrm{mg} \mathrm{kg}^{-1} \mathrm{day}^{-1}$ intravenously from day 10 before transplantation until bowel function was normal. Then CsA $(3.25 \mathrm{mg} / \mathrm{kg})$ was given orally twice a day with plasma levels range from 150 to $250 \mathrm{ng} / \mathrm{ml}$ during the first 40 days and then tapered.

On day +10 after transplantation, Hematopoietic reconstitution was seen in this patient. The duration from transplant to an absolute neutrophil count $>0.5 \times 10^{9} / \mathrm{L}$ and to a platelet count $>20 \times 10^{9} / \mathrm{L}$ was 13 and 19 days respectively. On day +12 and +27 the experiment of STR-DNA showed that the recipient's hematopoietic tissues are $100 \%$ donor derived. Engraftment was confirmed by a bone marrow aspirate and biopsy on day 23. The early complications such as Acute Graft Versus Host Disease (aGVHD) and Hepatic Veno-Occlusive Disease (hVOD) and infections were not detected within the first 3 months after transplantation. The cytomegalovirus infection was excluded by weekly examination.

Eight months after the transplantation, the patient suffered dyspnea on effort and dry cough, then she was treated with antibiotics, doxofylline, ambroxol and voriconazole. However her symptoms progressive increased. We diagnosed her Bronchiolitis Obliterans Syndrome (BOS) because high-resolution chest computed tomography scan showed the presence of air trapping during the expiratory phase which was represented by areas with hypoattenuation that correspond to obstructed airways interspaced with areas of ground glass appearance corresponding to the pulmonary lobules of patent airways. The pulmonary tests also showed obstructive ventilatory disorder accompanied with small airway function exception and significantly decreased diffusion function by spirometric data showing that FEV1/ FVC less than 0.7 and FEV1 25\% from the predicted value. She was then treated with methylprednisolone $\left(1 \mathrm{mg} \mathrm{kg}^{-1} \mathrm{~d}^{-1}\right)$ and azithromycin $(3 \mathrm{mg}$ $\left.\mathrm{kg}^{-1} \mathrm{~d}^{-1}\right)$. Her symptoms and the spirometric data were improved after 4 weeks of therapy. However, in parallel with corticosteroid tapering, her symptoms recurred again and pulmonary functions worsened.
After careful consideration she was therefore given an experimental treatment with human BMMSC. Her sister was chosen because Major Histocompatibility Complex (MHC) compatibility is not necessary for mesenchymal stem cell immunosuppression. After ethics committee approval and the patient's informed consent, $1.5 \times 10^{6}$ BMMSC per kg of the patient's weight was administered intravenously on day +275 and day +305 . No BMMSC infusion-related side effects were noted during and after the cell infusion. The patient had a significant response to this therapy, as demonstrated by the disappearance of lung symptoms and significantly improved pulmonary function. Now she continues to be asymptomatic with her pulmonary function within the normal ranges and tapering steroid dose was successfully achieved.

\section{Discussion}

Advances in haematopoietic stem cell transplantation techniques, and prophylaxis and treatment of infections, have significantly decreased the risks of infectious complications following transplantation [16]. As a result, late complications, including bronchiolitis obliterans syndrome, are increasingly becoming a major cause of morbidity and mortality following haematopoietic stem cell transplantation [17].

BOS often occurs after 3 months past transplantation. According to the literature, several risk factors are associated with the development of BOS such as older age of recipient, AFO prior to HSCT, early respiratory viral infection, busulfan-based conditioning regimen, methotrexate-based GVHD prophylaxis and cGVHD and so on [18-20]. Among them the most important association with BOS is the presence of cGVHD [21]. BOS is thought (although has not been proved) to be caused by cGVHD, in which the host lung epithelium activates donor cytotoxic $\mathrm{T}$ lymphocytes which target the bronchioles of the recipient and mount chronic rejection responses against lung allo-antigens $[3,7]$. Furthermore BOS is typically accompanied by allo-immune manifestations in other organs, for example, liver, eyes, or skin $[3,22]$. Ditschkows et al. [23] found that the depletion of $\mathrm{T}$ cells in grants to prevent GVHD before transplantation could avoid the appearance of BOS supporting the hypothesis that BOS is a manifestation of cGVHD in the lung.

The treatment of BOS faces lots of challenges. Despite aggressive immunosuppressive therapy, fewer patients had complete resolution of disease. In addition, despite a long course the eventual outcome for these patients is unsatisfactory $[16,24]$. This present a new question that novel therapies are essential. Recently more and more studies have suggest that MSCs have unique roles in immune suppression by inhibiting $\mathrm{T}$ cells proliferation $[25,26]$. Numerous clinical trials using MSCs to prevent and treat GVHD have been carried on world-widely [13], moreover MSCs are thought to suppress acute and chronic GVHD without damaging the graft-versus-leukemia effects thus representing a novel treatment for GVHD $[27,28]$. But the molecular mechanisms by which MSC suppress immune responses in vivo and in vitro are poorly understood. In addition, in vivo in humans, autologous and allogeneic MSC are safe to infuse with no acute adverse events and no longterm MSC associated adverse events [27,28]. Our case successfully demonstrated that the infusion of MSCs could significantly improve the symptoms of the patient associated with conventional treatment thus some patients with BOS after HSCT may benefit from MSC therapy in the future and MSCs might become one additional option for the treatment of BOS. 
Citation: Liang W, Xia H, Wang Y, Zhao RC (2012) Allogeneic Mesenchymal Stem Cells Injections for the Treatment of Bronchiolitis Obliterans Syndrome Following Allogeneic Hematopoietic Stem Cells Transplant. J Cancer Sci Ther 4: 185-187. doi:10.4172/1948-5956.1000138

\section{terest}

The authors declare no conflict of interest.

\section{References}

1. Clark JG, Crawford SW, Madtes DK, Sullivan KM (1989) Obstructive lung disease after allogeneic marrow transplantation. Clinical presentation and course. Ann Intern Med 111: 368-376.

2. Dudek AZ, Mahaseth H, DeFor TE, Weisdorf DJ (2003) Bronchiolitis obliterans in chronic graft-versus-host disease: analysis of risk factors and treatment outcomes. Biol Blood Marrow Transplant 9: 657-666.

3. Holland HK, Wingard JR, Beschorner WE, Saral R, Santos GW (1988) Bronchiolitis obliterans in bone marrow transplantation and its relationship to chronic graft-v-host disease and low serum IgG. Blood 72: 621-627.

4. Marras TK, Chan CK, Lipton JH, Messner HA, Szalai JP, et al. (2004) Longterm pulmonary function abnormalities and survival after allogeneic marrow transplantation. Bone marrow transplant 33: 509-517.

5. Tomas SLH, Loberiza FR Jr, Klein JP, Layde PM, Lipchik RJ, et al. (2005) Risk factors for bronchiolitis obliterans in allogeneic hematopoietic stem-cell transplantation for leukemia. Chest 128: 153-161.

6. Chien JW, Duncan S, Williams KM, Pavletic SZ (2010) Bronchiolitis obliterans syndrome after allogeneic hematopoietic stem cell transplantation-an increasingly recognized manifestation of chronic graft-versus-host disease. Biol Blood Marrow Transplant 16: S106-S114.

7. Kurland G, Michelson P (2005) Bronchiolitis obliterans in children. Pediatr pulmonol 39: 193-208.

8. Soubani AO, Uberti JP (2007) Bronchiolitis obliterans following haematopoietic stem cell transplantation. Eur Respir J 29: 1007-1019.

9. Clark JG (1990) The challenge of bone marrow transplantation. Mayo Clin proc 65: 111-114.

10. Chan CK, Hyland RH, Hutcheon MA, Minden MD, Alexander MA, et al. (1987) Small-airways disease in recipients of allogeneic bone marrow transplants. An analysis of 11 cases and a review of the literature. Medicine 66: 327-340.

11. Liang W, Xia H, Li J, Zhao RC (2011) Human adipose tissue derived mesenchymal stem cells are resistant to several chemotherapeutic agents. Cytotechnology 63: 523-530.

12. Yi T, Song SU (2012) Immunomodulatory properties of mesenchymal stem cells and their therapeutic applications. Arch pharm Res 35: 213-221.

13. Sato K, Ozaki K, Mori M, Muroi K, Ozawa K (2010) Mesenchymal stromal cells for graft-versus-host disease : basic aspects and clinical outcomes. J Clin Exp Hematop 50: 79-89.

14. Ren H, Cao Y, Zhao Q, Li J, Zhou C, et al. (2006) Proliferation and differentiation of bone marrow stromal cells under hypoxic conditions. Biochem biophys Res Commun 347: 12-21.
15. Liang W, Lu C, Li J, Yin JQ, Zhao RC (2010) p73alpha regulates the sensitivity of bone marrow mesenchymal stem cells to DNA damage agents. Toxicology 270: 49-56.

16. Uhlving HH, Buchvald F, Heilmann CJ, Nielsen KG, Gormsen M, et al. (2011) Bronchiolitis obliterans after allo-SCT: clinical criteria and treatment options. Bone marrow transplant [Epub ahead of print].

17. Lemonnier F, Dhedin N, Catherinot E, Tcherakian C, Neveu H, et al. (2011) Bronchiolitis obliterans postallogeneic stem cell transplantation: what is new? Rev pneumol clin 67: 258-266.

18. Prince DS, Wingard JR, Saral R, Santos GW, Wise RA (1989) Longitudinal changes in pulmonary function following bone marrow transplantation. Chest 96: 301-306

19. Chien JW, Maris MB, Sandmaier BM, Maloney DG, Storb RF, et al. (2005) Comparison of lung function after myeloablative and 2 Gy of total body irradiation-based regimens for hematopoietic stem cell transplantation. Bio Blood Marrow Transplant 11: 288-296.

20. Marras TK, Chan CK (2003) Obliterative bronchiolitis complicating bone marrow transplantation. Semin Respir Crit Care Med 24: 531-542.

21. Schultz KR, Green GJ, Wensley D, Sargent MA, Magee JF, et al. (1994) Obstructive lung disease in children after allogeneic bone marrow transplantation. Blood 84: 3212-3220.

22. Chien JW, Martin PJ, Gooley TA, Flowers ME, Heckbert SR, et al. (2003) Airflow obstruction after myeloablative allogeneic hematopoietic stem cel transplantation. Am J Respir Crit Care Med 168: 208-214.

23. Ditschkowski M, Elmaagacli AH, Trenschel R, Peceny R, Koldehoff M, et al. (2007) T-cell depletion prevents from bronchiolitis obliterans and bronchiolitis obliterans with organizing pneumonia after allogeneic hematopoietic stem cell transplantation with related donors. Haematologica 92: 558-561.

24. Nakaseko C, Ozawa S, Sakaida E, Sakai M, Kanda Y, et al. (2011) Incidence, risk factors and outcomes of bronchiolitis obliterans after allogeneic stem cel transplantation. Int J Hematol 93: 375-382.

25. Karlsson H, Samarasinghe S, Ball LM, Sundberg B, Lankester AC, et al. (2008) Mesenchymal stem cells exert differential effects on alloantigen and virusspecific T-cell responses. Blood 112: 532-541.

26. Le Blanc K, Ringden O (2007) Immunomodulation by mesenchymal stem cells and clinical experience. J Intern Med 262: 509-525.

27. Chen X, Armstrong MA, Li G (2006) Mesenchymal stem cells in immunoregulation. Immunol Cell Biol 84: 413-421.

28. Moll G, Jitschin R, von Bahr L, Rasmusson-Duprez I, Sundberg B, et al. (2011) Mesenchymal stromal cells engage complement and complement recepto bearing innate effector cells to modulate immune responses. PloS One 6 : e21703. 